\title{
DIREITOS HUMANOS E OS DESAFIOS À SOLIDARIEDADE INTERGERACIONAL NO CENÁRIO DE CRISE AMBIENTAL GLOBAL
}

João Henrique Souza dos Reis
Lívia Gaigher Bósio Campello

Resumo: As preocupações da humanidade com a degradação ambiental e suas consequências justificam este artigo, que expõe aspectos principais da proteção ambiental para as futuras gerações com fundamento no princípio da solidariedade. Para isto, objetiva demonstrar o conteúdo dos direitos de solidariedade, abordar a degradação ambiental como um desafio do mundo globalizado e examinar a repercussão da solidariedade intergeracional como garantidora dos direitos humanos. Para alcançar os objetivos almejados, utiliza-se a pesquisa exploratória, descritiva, bibliográfica e documental, com análise por meio de obras, artigos, declarações, convenções internacionais. O método de abordagem é o dedutivo, partindo de conceitos genéricos até sua particularização.

Palavras-chave: Globalização, Solidariedade Intergeracional, Proteção Ambiental, Futuras Gerações, Direitos Humanos.

\section{HUMAN RIGHTS AND THE CHALLENGES TO INTERGENERATIONAL SOLIDARITY IN THE GLOBAL ENVIRONMENTAL CRISIS SCENARIO}

\begin{abstract}
The humanity concerns with environmental degradation and its consequences justify the reason for this paper, which demonstrates the main aspects of environmental protection for future generations based on the principle of solidarity. To this end, it aims to demonstrate the content of solidarity rights, to introduce environmental degradation as a challenge of the globalized world and to examine intergenerational solidarity as a human rights guarantor. To reach these objectives, this paper uses exploratory, descriptive, bibliographical and documentary research with analysis through works, articles, declarations, and international conventions. The approach method is the deductive, starting from generic concepts until its particularization.

\footnotetext{
${ }^{1}$ Mestrando em Direito pela Fundação Universidade Federal de Mato Grosso do Sul - UFMS. Graduação em Direito pela Fundação Universidade Federal de Mato Grosso do Sul - UFMS. Membro do Grupo de Pesquisa "Direitos Humanos, Meio Ambiente e Desenvolvimento Sustentável Global" (CNPq). Endereço postal: Rua Praia da Costa, 113, CEP 79.022-403, Campo Grande - Mato Grosso do Sul. Endereço eletrônico: joaohenrique.reis@ hotmail.com.

${ }^{2}$ Pós-Doutorado em Direito do Estado pela Universidade de São Paulo - USP, Doutorado em Direito das Relações Econômicas e Internacionais pela Pontifícia Universidade Católica de São Paulo - PUC/SP e Mestrado em Políticas Públicas e Processo pelo Centro Universitário Fluminense - UNIFLU. Professora adjunta da Faculdade de Direito na Universidade Federal de Mato Grosso do Sul (UFMS). Coordenadora do Programa de Mestrado em Direitos Humanos da UFMS. Coordenadora do Projeto de Pesquisa "Cooperação Internacional e Meio Ambiente" (MS/FUNDECT). Líder do Grupo de Pesquisa "Direitos Humanos, Meio Ambiente e Desenvolvimento Sustentável
} Global" (CNPq). Editora-chefe da Revista Direito UFMS. Endereço eletrônico: livia.campello@ufms.br.
\end{abstract}

Revista de Direitos Humanos em Perspectiva | e-ISSN: 2526-0197 | Porto Alegre | v. 4 | n. 2 | p. 124 - 145 | Jul/Dez. 2018 
Keywords: Globalization, Intergenerational Solidarity, Environmental Protection, Future Generations, Human Rights.

\section{INTRODUÇÃO}

Os direitos humanos de terceira dimensão no mundo globalizado enfrentam muitos desafios. Dentre os inúmeros desafios existentes, o presente artigo abordará, especificamente, a questão da degradação ambiental e a proteção do meio ambiente para as futuras gerações através do princípio da solidariedade, com a justificativa de que a problemática ambiental afeta os direitos humanos das presentes e futuras gerações.

A ideia de que o meio ambiente e os direitos humanos são indissociáveis vem sendo amplamente aceita pela comunidade internacional, principalmente após a Declaração de Estocolmo fruto da Convenção das Nações Unidas sobre Meio Ambiente e Desenvolvimento de 1972 e a Conferência das Nações Unidas para o Meio Ambiente e Desenvolvimento de 1992, conhecida como Rio-92, que deu origem ao Programa das Nações Unidas sobre Meio Ambiente (PNUMA). A mencionada indissociabilidade se deve, principalmente, ao fato de que quando há violação ao direito ao meio ambiente, também há violação aos direitos humanos, por exemplo, quando o acesso ao meio ambiente ecologicamente equilibrado é restringido, assim como quando a qualidade de vida das pessoas é prejudicada devido à degradação ambiental.

Nesse contexto, eis o problema a ser tratado no presente artigo: com a degradação ambiental cada vez mais trazendo riscos às futuras gerações, como e por que proteger o meio ambiente para as futuras gerações, sendo estas indeterminadas e indetermináveis?

Para a abordagem da problemática mencionada objetiva-se expor os aspectos principais dos direitos humanos de terceira dimensão, sintetizando como se chegou ao consenso e consagração dos direitos humanos de solidariedade, ainda, tratar-se-á da questão da degradação ambiental como um desafio trazido pela globalização e, por fim, verificar-se-á se a solidariedade intergeracional pode ser a ferramenta de efetivação da proteção ambiental para as futuras gerações no mundo globalizado atual.

A fim de alcançar os objetivos almejados, será utilizada a pesquisa exploratória e descritiva, bibliográfica e documental, com uma análise por meio de obras, artigos, declarações, 
convenções internacionais. O método de abordagem será o dedutivo, partindo de conceitos genéricos até sua particularização.

\section{OS DIREITOS HUMANOS DE TERCEIRA DIMENSÃO: A CONSAGRAÇÃO DOS DIREITOS DE SOLIDARIEDADE}

Inicialmente, esclarece-se que as dimensões de direitos humanos coexistem e complementam-se umas às outras, não substituindo ou extinguindo dimensões anteriores, motivo pelo qual o presente trabalho optou por utilizar o termo "dimensão" em vez de "geração", tendo em vista que o segundo termo pode passar a ideia de que as "gerações" anteriores estariam superadas.

A terminologia "dimensão" é a defendida por Bonavides:

Força é dirimir, a esta altura, um eventual equívoco de linguagem: o vocábulo "dimensão" substitui, com vantagem lógica e qualitativa o termo "geração", caso este último venha a induzir apenas sucessão cronológica e, portanto, suposta caducidade dos direitos das gerações antecedentes, o que não é verdade. Ao contrário, os direitos da primeira geração, direitos individuais, os da segunda, direitos sociais, e os da terceira, direitos ao desenvolvimento, ao meio ambiente, à paz e à fraternidade, permanecem eficazes, são infraestruturais, foram a pirâmide cujo ápice é o direito à democracia. (BONAVIDES, 2004, pp. 571572).

Além disso, importa elucidar a diferença entre direitos humanos e direitos fundamentais:

Os Direitos Humanos, a partir dos espaços de luta, foram sendo normatizados em Tratados Internacionais e pretendem a característica de universalidade. Por outro lado, os Direitos Fundamentais são Direitos essenciais à pessoa humana, definidos na Constituição de um Estado, contextualizados conforme a política do país, ou seja, os Direitos Fundamentais são Direitos Humanos constitucionalizados. (SANCHES, 2011, p. 295).

Após a Segunda Guerra Mundial e as diversas atrocidades e massacres que tiveram início com o fortalecimento do totalitarismo estatal na década de 1930, a humanidade entendeu, como nunca havia aprendido antes, o valor superior da dignidade da pessoa humana. A aprovação, pela Assembleia Geral das Nações Unidas, da Declaração Universal, em 1948, e a Convenção Internacional sobre a Prevenção e Punição do Crime de Genocídio, aprovada no 
mesmo ano, são os marcos iniciais da nova fase histórica dos direitos humanos. (COMPARATO, 2015, pp. 68-69).

Esta nova fase histórica é marcada pela definitiva internacionalização dos direitos humanos e seu aprofundamento, pois, após o término da Segunda Guerra Mundial, foram realizadas, no âmbito da Organização das Nações Unidas e das organizações regionais, diversas convenções internacionais dedicadas à matéria. Desta maneira, não só direitos individuais, de natureza civil e política, e os direitos de conteúdo econômico e social foram estabelecidos no direito internacional, mas também novas espécies de direitos humanos, como os direitos dos povos e os direitos da humanidade. (COMPARATO, 2015, p. 69).

Da necessidade de expandir os direitos humanos a todos surgiu a terceira dimensão dos direitos humanos. Exemplificando, há o direito à autodeterminação, que vem para se opor à crescente desigualdade nos acordos comerciais, continuamente desfavoráveis aos países produtores de matérias-primas, trazendo à tona, aparentemente, nas relações assimétricas da globalização, a hegemonia econômica que certas nações exerciam na época colonial. (SILVEIRA; ROCASOLANO, 2010, p. 157).

É interessante trazer uma perspectiva histórica do surgimento dos direitos humanos de terceira dimensão:

Dois Pactos Internacionais, celebrados no quadro das Nações Unidas em 1966, compendiaram o conjunto dos direitos civis e políticos, bem como os direitos econômicos, sociais e culturais. Em 1981, na Carta Africana dos Direitos Humanos e dos Povos, reconheceu-se que todos os povos devem ser tratados com igual respeito, tendo direito à autodeterminação, à livre disposição de sua riqueza e de seus recursos naturais, ao desenvolvimento econômico, social e cultural, bem como à paz e à segurança. Chegou-se enfim ao reconhecimento de que à própria humanidade, como um todo solidário, devem ser reconhecidos vários direitos: à preservação de sítios e monumentos, considerados parte integrante do patrimônio mundial, à comunhão nas riquezas minerais do subsolo marinho, à preservação do equilíbrio ecológico do planeta. (COMPARATO, 2015, pp. 69-70).

A contrapartida dos direitos humanos são deveres da mesma natureza. Até o reconhecimento dos direitos econômicos, sociais e culturais, os deveres correspondentes aos direitos humanos eram considerados incumbidos apenas ao Estado. Hoje, reconhece-se que, além dos Poderes Públicos, todos os indivíduos e as pessoas jurídicas de direito privado têm o dever de respeitar os direitos humanos de qualquer espécie. (COMPARATO, 2015, p. 70). 
Desta maneira, a terceira dimensão dos direitos humanos consagra os direitos de solidariedade, que podem ser entendidos como o direito à paz, meio ambiente sadio, autodeterminação dos povos e desenvolvimento econômico. Existe um número crescente de circunstâncias e comportamentos humanos, decorrentes de um mundo globalizado e em um contexto econômico de capitalismo avançado, que exige maiores ações de proteção e de prestação por parte do Estado. Os direitos de solidariedade, além de relativizarem a soberania dos Estados, também comprometem o indivíduo com a pauta de direitos. (SANCHES, 2011, p. 297).

Com o intuito de superar e corrigir o individualismo da civilização burguesa, que era fundado nas liberdades privadas e na isonomia, surge, no século XIX, o princípio da solidariedade como dever jurídico, mesmo que a fraternidade como virtude cívica fosse inexistente no meio social. (COMPARATO, 2015, p. 78). Nessa perspectiva, o fundamento ético do princípio da solidariedade é localizado na ideia de justiça distributiva:

A solidariedade prende-se à ideia de responsabilidade de todos pelas carências ou necessidades de qualquer indivíduo ou grupo social. É a transposição, no plano da sociedade política, da obligatio in solidum do direito privado romano. O fundamento ético desse princípio encontra-se na ideia de justiça distributiva, entendida como a necessária compensação de bens e vantagens entre as classes sociais, com a socialização dos riscos normais da existência humana. (COMPARATO, 2015, p. 79).

Monstesquieu (1817, p. 584) teceu uma frase na qual traz o sentido ético do princípio da solidariedade:

Se eu soubesse algo que fosse útil para mim e prejudicasse minha família, rejeitaria isso de meu espírito. Se eu soubesse algo que fosse útil para minha família e não fosse útil para meu país, tentaria esquecer. Se eu soubesse algo útil para o meu país e que fosse prejudicial à Europa, ou que fosse útil à Europa, mas prejudicial à raça humana, consideraria isto como um crime.

Conforme Lívia Gaigher B. Campello e Angela Calixto, a solidariedade agiu como uma concepção revolucionária no direito:

A solidariedade foi introduzida como um conceito verdadeiramente revolucionário no direito, pois no contexto de busca para lidar com a situação das desigualdades econômicas, a sociedade havia desenvolvido opiniões diferentes para dirimi-la. Inicialmente, a ideia cristã de caridade se tornou influente, destacando-se o papel da filantropia. Entretanto, o conceito de solidariedade se apresentou com conteúdo diferente, em contraste com as noções verticalizadas de caridade ou filantropia, em que o doador sente piedade, sendo, portanto, misericordioso. O conceito de solidariedade, por sua vez, se firmou 
com base em uma relação horizontal de igualdade entre doador e receptor. A ajuda passou a ser entendida, assim, não como um ato de misericórdia, mas como um direito de todo cidadão, guiada pela ideia de igualdade entre os cidadãos, reciprocidade e responsabilidade compartilhada nas suas relações. Esta noção de solidariedade, representada pela ideia de compartilhar com o outro cidadão, por ser igual e merecedor de uma política comum, passou então a formar um novo conceito central na modernidade. (CAMPELLO; CALIXTO, 2017, p. 10).

Então, tem-se que o conceito de solidariedade é inovador ao estabelecer uma relação de reciprocidade, que se relaciona com os conceitos de equidade e igualdade, formando uma relação horizontalizada, substituindo a relação doador-receptor e dando lugar à relação doador-receptor e receptor-doador, no sentido de compartilhamento mútuo, o mesmo ente ou indivíduo pode ser doador em uma situação e receptor em outra.

A ideia filosófica de fraternidade é a base histórica da expressão solidariedade. Foi com a Revolução Francesa de 1789, que trouxe o lema "Liberdade, Igualdade e Fraternidade", que o conceito de fraternidade passou a ser disseminado como princípio universal de modo a exercer influência em institutos jurídicos e em ideais no mundo. A solidariedade, originariamente como uma espécie de reinvindicação para ajuda aos mais pobres, foi integrada à Declaração dos Direitos do Homem e do Cidadão de 1793, como obrigação de parte da sociedade de proporcionar subsistência às pessoas necessitadas. (CAMPELLO; CALIXTO, 2017, p. 10).

Nesse sentido, quanto à relação de reciprocidade estabelecida pelo conceito de solidariedade:

A preocupação com o conceito de solidariedade ganha corpo e preponderância no decorrer da história, motivo pelo qual é importante esclarecer que a solidariedade não pode ser definida como divisor do mundo, onde de um lado estão os que dão e de outro os que recebem, já que, pelo contrário, apoia-se na ideia de todos devem contribuir, da mesma forma que todos poderão se beneficiar desta contribuição conforme suas necessidades. Expressão de igual dignidade entre os homens, a solidariedade atua como um freio à extensão da lógica mercantil e a outras consequências advindas da globalização, entendendose que a organização da solidariedade é uma questão de futuro que se coloca em qualquer sociedade. (MELEU; BANDEIRA, 2017, p. 271).

O conceito de solidariedade tornou-se internacional desde o século XIX, vindo a ser exigida em todo o mundo. E isto se deve à consciência adquirida, principalmente após a Segunda Guerra Mundial, acerca da interdependência entre os direitos políticos, econômicos, sociais e 
ecológicos. Após o final da mencionada guerra, foi assinada por 51 países a Carta fundadora da Organização das Nações Unidas (ONU), que proclamou os direitos humanos e a dignidade da pessoa humana. Os direitos dos povos (ou seres humanos) ficaram conceituados como direitos de solidariedade, terminando de formar as três gerações de direitos humanos com o tríplice lema da Revolução Francesa, que era "liberdade, igualdade e fraternidade (solidariedade)". (CAMPELLO; CALIXTO, 2017, p. 11).

Os direitos de solidariedade, por serem destinados à humanidade como um todo, buscam proteger, além das presentes gerações, as gerações futuras:

Essa nova abordagem universalista dada pelo direito internacional aos direitos humanos é fundamentada e justificada pelo princípio da solidariedade. A terceira geração dos direitos humanos, ou "direitos de solidariedade", não apenas reivindica, no ordenamento jurídico internacional, a proteção de direitos do ser humano visto individualmente, como faz a primeira geração; ou dentro de coletividades determinadas, como faz a segunda; mas sim do gênero humano como um todo, sendo responsável por sintetizar e garantir a realização efetiva dos direitos de primeira e segunda gerações para toda a humanidade. A solidariedade inspira a preocupação com diversos temas de caráter difuso e global, que por isso afetam todo o gênero humano, como a paz, o meio ambiente, o desenvolvimento, o patrimônio comum da humanidade, a comunicação, a proteção contra as armas nucleares e a biossegurança. Na medida em que o sujeito de tais direitos é toda a humanidade, eles não são restritos à proteção das gerações atuais, mas também das que ainda estão por vir. (SILVEIRA, 2015, p. 110).

Segundo Comparato (2015, p. 51) há dois grandes fatores de solidariedade humana, sendo o primeiro de ordem técnica, transformador dos meios ou instrumentos de convivência, mas indiferente aos fins, e o segundo de natureza ética, que procura sujeitar a vida social ao valor supremo de justiça.

A padronização dos costumes e modos de vida, por meio da homogeneização universal das formas de produção, trabalho e troca de bens, por intermédio da globalização dos meios de comunicação e transporte, é a solidariedade técnica, enquanto a solidariedade ética é a que se baseia no respeito aos direitos humanos, de maneira a estabelecer bases para a concepção de uma cidadania mundial, sem relações de dominação, seja ela individual ou coletiva. (COMPARATO, 2015, p. 51). E, ainda, segundo Comparato (2015, p. 51), as duas formas de solidariedade mencionadas se complementam e são "indispensáveis para que o movimento de unificação da humanidade não sofra interrupção ou desvio." 
A questão dos direitos humanos de solidariedade, no fim da década de 1960, se fortaleceu, o que deu origem a normas de soft law da Organização das Nações Unidas, como: a Declaração sobre Meio Ambiente Humano de 1972, que afirmou o direito ao meio ambiente como direito humano inalienável; a proclamação do direito humano à paz, em 1976, pela antiga Comissão de Direitos Humanos, sendo em 1978 incorporado pela Declaração sobre o Direitos dos Povos à Paz; a primeira menção ao direito humano ao desenvolvimento na ONU, em 1981, que, em 1986, foi proclamado na Declaração sobre o Direito ao Desenvolvimento. (CAMPELLO; CALIXTO, 2017, p. 11).

Assim como em outras áreas nas quais há presença de normas de soft law, no direito internacional do meio ambiente a repetição é um fator muito importante no processo legislativo de criação de normas de soft law. A recorrente invocação das mesmas regras de maneiras diferentes, em vários instrumentos de nível universal, regional e local, transmitindo basicamente a mesma mensagem, tende a, progressivamente, desenvolver e estabelecer um entendimento internacional comum. Como resultado desse processo, condutas e comportamentos que seriam considerados violações à soberania dos Estados vinte anos atrás, hoje são aceitas como padrão. (DUPUY, 1991, p. 425).

No contexto das normas de soft law, quando acabam por ser editadas várias normas no mesmo sentido, mesmo que em instrumentos que não são juridicamente vinculantes justamente por constituírem normas de soft law, essas acabam por ajudar a expressar a opinio juris da comunidade internacional acerca de determinado assunto, pela reiteração de princípios idênticos. (DUPUY, 1991, p. 432).

E, como se sabe, a opinio juris concatenada com a prática reiterada de determinadas condutas pelos Estados, alimentam o direito consuetudinário. Quanto à necessidade de observância dos direitos de solidariedade, consolidou-se uma opinio iuris:

Ainda que não houvesse a iniciativa para elaboração de uma declaração específica sobre o direito de solidariedade, a presença de referências expressas à imprescindibilidade de solidariedade internacional em diversos instrumentos internacionais já demonstra que tal direito se encontra reconhecido pela comunidade internacional, tendo-se consolidado uma opinio juris quanto à necessidade de sua observância. Com efeito, eventual reconhecimento do direito em novas declarações, resoluções ou tratados internacionais não levaria à criação de novas obrigações entre os Estados, mas apenas conferiria maior peso às obrigações já existentes, implementando e concretizando a proteção dos 
direitos de solidariedade e, consequentemente, dos direitos de primeira e segunda geração. (CAMPELLO; CALIXTO, 2017, p. 21).

Mesmo sendo "apenas soft law", juridicamente não vinculantes, tais normas são relevantes no cenário internacional da proteção do meio ambiente, por muitas vezes refletirem padrões de comportamentos que são esperados dos Estados de maneira mais rápida, em relação a uma norma de hard law, além de influenciar a criação desta última.

Portanto, pode-se concluir o presente tópico com a afirmação de que o princípio da solidariedade, após ser reafirmado em diversas normas de soft law, no sentido de existir uma imprescindibilidade de solidariedade internacional, está de acordo com a opinio iuris da comunidade internacional, devendo ser seguido e respeitado.

\section{A GLOBAlizaÇÃo E SEUS EFEITOS NO PROCESSO DE DEGRADAÇÃo AMBIENTAL}

A evolução tecnológica do século $\mathrm{XX}$ trouxe um desenvolvimento nunca visto à humanidade, com visíveis aprimoramentos nas condições de vida do ser humano, mas, ao mesmo tempo, trouxe uma devastação ambiental também nunca vista antes, e, desta vez, em nível global.

Inicialmente, o significado de globalização pode ser tido como ausência de um centro, uma espécie de descentralização:

O significado mais profundo transmitido pela ideia da globalização é o do caráter indeterminado, indisciplinado e de autopropulsão dos assuntos mundiais; a ausência de um centro, de um painel de controle, de uma comissão diretora, de um gabinete administrativo. A globalização é a "nova desordem mundial" de Jowitt com um outro nome. (BAUMAN, 1999, p. 58).

Bauman (1999, p. 59) continua explanando que o termo "globalização" atualmente se refere, principalmente "aos efeitos globais, notoriamente não pretendidos e imprevistos, e não às iniciativas e empreendimentos globais". Vem à tona, no atual mundo globalizado, a indispensabilidade da terceira dimensão de direitos humanos, com os direitos de solidariedade, tendo em vista que ações individuais podem produzir efeitos globais:

No interior da densa rede mundial de interdependência global, não podemos estar seguros de nossa inocência moral sempre que os outros seres humanos sofram por falta de dignidade, miséria ou sofrimento. Não podemos declarar que

Revista de Direitos Humanos em Perspectiva | e-ISSN: 2526-0197 | Porto Alegre | v. 4 | n. 2 | p. 124 - 145 | Jul/Dez. 2018 
não sabemos, nem ter certeza de que não haja nada que possamos mudar em nossa conduta para evitar ou, pelo menos, aliviar a sorte dos sofredores. Talvez sejamos impotentes individualmente, mas poderíamos fazer algo juntos, e a "integração" é formada de e por indivíduos (BAUMAN, 2011, pp.78-79).

Uma conceituação mais ampla de globalização é a de que esta é um conjunto de processos complexos, contraditórios, heterogêneos e profundos, de natureza política, jurídica e ecológica. Processos os quais produzem transformações radicais nas relações entre sociedades, nações e culturas, gerando uma espécie de interdependência nas esferas econômica, política e cultural, pela qual se desenvolve o processo atual de integração global e determina, em última análise, a esfera econômica, pelo controle exercido por grandes empresas multinacionais sob a ideologia neoliberal. (TORRADO, 2012, p. 53).

É importante mencionar que o termo "universalização" não se confunde com o termo "globalização", sendo entendido como "uma reação ao aspecto colonizador e imperialista da globalização”. (AGUILERA URQUIZA; RIBEIRO, 2017, p. 245). Ainda, a universalização, na perspectiva dos direitos humanos, possui um conceito mais aberto à integração cultural, enquanto a globalização possui um caráter ideológico mais impositivo:

[...] a distinção mais evidente entre ambos os termos é que a universalização, além de ser um conceito com origem histórica diversa da globalização, possuiria, principalmente no âmbito dos Direitos Humanos, um teor mais aberto à integração multicultural, ao passo que a globalização teria um caráter ideológico mais impositivo nesse sentido, que pode acarretar, na verdade, a exclusão da diversidade cultural. A universalização estaria mais vinculada a ideia de ampliação e desenvolvimento moral para todas as sociedades humanas, enquanto a globalização seria referente mais ao de progresso instrumental. (TORRADO apud AGUILERA URQUIZA; RIBEIRO, 2017, p. 245).

Ou seja, a globalização é um conceito de caráter ideológico impositivo, que, de forma ampla e intensa, norteia as relações nacionais e internacionais, de maneira a trazer consequências incertas na perspectiva do desenvolvimento humano, uma vez que algumas consequências imediatas da globalização não têm se traduzido em uma qualidade de vida melhor para a sociedade humana. (AGUILERA URQUIZA; RIBEIRO, 2017, p. 246).

Uma dessas incertezas é o problema da proteção ambiental para as futuras gerações, uma vez que a globalização está relacionada com problemas como, por exemplo, a aceleração do 
processo de degradação ambiental, o aumento dos efeitos negativos das mudanças climáticas, a polarização norte-sul, a explosão demográfica e o consumismo.

A título de exemplificação, o problema da polarização norte-sul possui como um de seus aspectos o fato de que grande parte dos danos ambientais que atingem o sul são ocasionados devido a uma produção voltada para a exportação com o objetivo de atender as necessidades do norte, em vez das necessidades do sul, sendo o norte o responsável por consumir mais de $80 \%$ da produção econômica global, apesar de em termos populacionais representar apenas $20 \%$ ou menos da humanidade. (CANCIO; CAMPELLO, 2016, p. 71).

Ainda, como exemplo, há o problema do consumismo, causado pela globalização, que, para Bustamante (apud MORAES, 2013, p. 39), é originado por necessidades geradas artificialmente devido ao sistema de produção, que as transformam em necessidades culturais, através de práticas como a obsolescência programada.

Os problemas da globalização, muitas vezes, atingem a humanidade de maneira que somente a solidariedade poderia mudar esse cenário:

O Estado encontra-se enfraquecido perante o fenômeno da globalização e busca na criminalização da miséria uma das formas de controlar a pobreza, situação esta inaceitável, até porque a classe baixa é a que mais sofre com a restrição de direitos e ainda terá que lidar com o sentimento de "aporofobia" por parte de quem se beneficia do processo de globalização. Afinal de contas, tecnologia avançada para quem? Poder de consumo para quem? Direitos humanos em prol de quem? O lado "negro" da globalização encontra-se bem localizado (nas periferias, ou nas classes baixas). Assim, acredita-se que somente um ideal de solidariedade em sentido global promete mudar este cenário e, por isso, há a necessidade de reafirmar os direitos do homem que foram arduamente conquistados ao longo do tempo. (MELEU; BANDEIRA, 2017, p. 270).

A globalização e o modo de vida capitalista e consumista atual, que busca a continuidade da marcha industrial transnacional, fazem com que empresas migrem para países em desenvolvimento e subdesenvolvidos, mas não com o intuito de trazer melhor qualidade de vida e garantir o mínimo existencial à população, e, sim, o de maximizar os lucros através da mão de obra barata e da imposição de sua força política em tais países. (PISSALDO, 2015, p. 71).

No mesmo sentido, em alguns países ocidentais, após a ratificação de tratados internacionais que tratam de sustentabilidade, desenvolvimento e direitos humanos, ocorre a migração de empresas para que os índices econômicos das transnacionais continuem em alta: as transnacionais mudam suas operações, principalmente dos setores fabris, para os países nos quais 
a fiscalização não é tão rígida quanto nos seus países de origem, no que diz respeito aos direitos humanos. (PISSALDO, 2015, p. 71).

Muitas vezes, utiliza-se o discurso de levar os benefícios da globalização aos países subdesenvolvidos ou em desenvolvimento para maximizar lucros, sem garantir os direitos humanos:

Estas afirmativas, invariavelmente resultam em violações de normas e de Direitos Humanos nos países em que se instalam, sob o discurso de estarem levando benesses da globalização e por conta da falência estatal, garantem força para penetrarem cada vez mais nessas localidades. As violações de Direitos Humanos preexistentes nesses locais são como permissões para que as transnacionais se instalem e levem a ilusão de entrega da Solidariedade como Direito Humano por meio da horizontalização dessas obrigações. (PISSALDO, 2015, p. 71).

Percebe-se, portanto, que o ideal da globalização, que pode ter efeitos positivos, como trazer mais prosperidade ao mundo e um aumento da qualidade de vida de todos os seres humanos, não vem se concretizando, preponderando, muitas vezes, seus efeitos negativos, que se traduzem em efeitos globais desordenados que são aproveitados por grandes empresas com o intuito de maximizar seus lucros, mesmo que disto decorram consequências negativas para os direitos humanos, como a degradação ambiental e a sua consequente incógnita: sem que o princípio da solidariedade seja de fato efetivado, haverá um meio ambiente sadio e equilibrado para as futuras gerações humanas?

\section{DESENVOLVIMENTO SUSTENTÁVEL, SOLIDARIEDADE INTERGERACIONAL E AS NECESSIDADES DAS FUTURAS GERAÇÕES}

A preocupação com as futuras gerações é perceptível no mundo inteiro e em diversas culturas, sendo, portanto, um valor universal da humanidade. Tal valor é fundamental nos tratados internacionais e constituições nacionais. (ONU, 2013, p. 2).

Já o desenvolvimento sustentável traz um compromisso de equidade para com as futuras gerações. Assim, em 1972, a Conferência de Estocolmo reconheceu que há a responsabilidade de proteger e melhorar o meio ambiente para as presentes e futuras gerações. (WEISS, 1992, p. 1). A Declaração de Estocolmo sobre Meio Ambiente Humano (1972, p. 3), preocupou-se com as 
gerações futuras em seus princípios 2 e $5 .^{3}$ A Conferência das Nações Unidas sobre Meio Ambiente e Desenvolvimento (1992, p. 154) também trouxe a solidariedade intergeracional em seu princípio $3 .^{4}$

Percebe-se que, com o objetivo de que o princípio da solidariedade consiga alcançar sua função justificadora em relação às limitações postas para a efetivação do direito ao meio ambiente, é fundamental que se entenda que tal direito possui um sujeito indeterminado e indeterminável como titular, pois consagra as gerações futuras como detentoras do direito a um meio ambiente sadio e de uma vida com qualidade. (MARQUES, 2012, p. 49).

Estudos científicos permitem à sociedade internacional entender os impactos a longo prazo de suas ações, enquanto o avanço tecnológico permite que as consequências danosas de certas ações contra o meio ambiente sejam reduzidas. Ocorre que as futuras gerações não possuem força política e a representação de seus interesses, de modo que ficam limitadas às preocupações das presentes gerações. (ONU, 2013, p. 2).

O Relatório Brundtland, intitulado Nosso Futuro Comum (1987, p. 16) mencionou, nesse sentido, que:

Nós agimos como agimos porque podemos escapar impunes: gerações futuras não votam, elas não possuem qualquer poder político ou financeiro; elas não podem questionar nossas decisões. Mas os resultados dos comportamentos atuais estão reduzindo rapidamente as opções para as futuras gerações. A maioria dos tomadora de decisões de hoje estarão mortos antes do planeta sentir os efeitos mais graves da chuva ácida, do aquecimento global, do esgotamento da camada de ozônio, da desertificação generalizada e da extinção de espécies.

Na lógica do desenvolvimento sustentável, a solidariedade intergeracional vai além das relações entre as diferentes gerações presentes para alcançar as gerações futuras, as quais ainda não existem. Em 1995, na Cúpula Mundial para o Desenvolvimento Social, países se comprometeram a criar um plano de ação para assegurar a equidade entre gerações e proteger a integridade e o uso sustentável do meio ambiente. Nesta perspectiva, a humanidade formaria uma

\footnotetext{
${ }^{3}$ Princípio 2: Os recursos naturais da terra incluídos o ar, a água, a terra, a flora e a fauna e especialmente amostras representativas dos ecossistemas naturais devem ser preservadas em benefício das gerações presentes e futuras, mediante uma cuidadosa planificação ou ordenamento.

Princípio 5: Os recursos não renováveis da terra devem empregar-se de forma que se evite o perigo de seu futuro esgotamento e se assegure que toda a humanidade compartilhe dos benefícios de sua utilização.

4 Princípio 3: "O direito ao desenvolvimento deve ser exercido de modo a permitir que sejam atendidas equitativamente as necessidades ambientais e de desenvolvimento de gerações presentes e futuras".
}

Revista de Direitos Humanos em Perspectiva | e-ISSN: 2526-0197 | Porto Alegre | v. 4 | n. 2 | p. 124 - 145 | Jul/Dez. 2018 
comunidade intergeracional na qual todos se respeitam e cuidam uns dos outros, alcançando o objetivo comum de sobrevivência da humanidade. (ONU, 2013, p. 3).

A solidariedade intergeracional forma a base do conceito de desenvolvimento sustentável: não se deve satisfazer as necessidades das presentes gerações às custas das necessidades das gerações futuras ou reduzindo suas oportunidades à uma vida boa e digna. As gerações presentes precisam decidir o fundamento moral sobre o qual agir acerca das gerações futuras, ainda mais quando sacrifícios significativos estão envolvidos. É preciso entender que deixar o planeta para seus descendentes em condições tão boas quanto a que puderam desfrutar é a coisa certa ou boa a se fazer. (ONU, 2013, pp. 3-4).

Do reconhecimento internacional e constitucional do direito das futuras gerações a um meio ambiente ecologicamente equilibrado, emerge a solidariedade intergeracional como uma imposição ao Estado e à sociedade de garanti-lo, mesmo que tais futuras gerações ainda não existam ou não se saiba se de fato existirão.

Há uma ideia abordada por Weiss de equidade intergeracional baseada em três princípios. Estes princípios reconhecem o direito de cada geração a usar os recursos da Terra para seu próprio benefício, mas restringem as ações das presentes gerações em relação a este uso, sem impor como cada geração deve administrar seus recursos. (WEISS, 1992, p. 10).

No mesmo sentido, tais princípios não exigem que as presentes gerações prevejam ou estimem as necessidades e preferências das futuras gerações, algo que seria extremamente difícil, ou, até mesmo, impossível. Em vez disso, tais princípios buscam garantir um alicerce de recursos naturais razoavelmente seguro e flexível para que as futuras gerações possam satisfazer seus próprios interesses e preferências. Tais prolegômenos são geralmente compartilhados por diversas culturas, sistemas econômicos e políticos. (WEISS, 1992, p. 10).

O Princípio da Conservação de Opções se traduz no fato de cada geração possui o dever de conservar a diversidade de recursos naturais e culturais existentes, para não diminuir as opções das futuras gerações na resolução de seus problemas e na satisfação de seus interesses, as futuras gerações devem ter direito a uma diversidade de recursos comparável àquela apreciada pelas gerações anteriores. (WEISS, 1992, p. 10).

Já o Princípio da Conservação da Equidade se baseia no entendimento de que se deve exigir de cada geração a manutenção da qualidade da Terra, para que não a deixem em condição 
pior a que encontraram, as futuras gerações devem ter direito a uma qualidade planetária comparável àquela desfrutada pelas gerações anteriores. (WEISS, 1992, p. 10).

Por fim, o Princípio da Conservação do Acesso traz a ideia de que cada geração deve proporcionar aos seus integrantes um acesso equitativo aos recursos naturais deixados pelas gerações passadas e devem conservar tais recursos para que as futuras gerações também tenham esse acesso. (WEISS, 1992, p. 10).

Percebe-se que esse conjunto de princípios, que forma a ideia de equidade intergeracional, busca a manutenção das condições ambientais, além do acesso aos recursos naturais em igual qualidade e quantidade, podendo servir como base da solidariedade intergeracional e devendo-se buscar o seu efetivo cumprimento.

Weiss entende, por meio de seu modelo de equidade, que há um dever das presentes gerações em relação às futuras, de não deixar um meio ambiente global em pior estado do que aquele de que hoje desfrutamos. (WEISS; D'AMATO; GÜNDLING, 1990, p. 190).

Um contraponto a esta visão de Weiss pode ser conferido no trecho a seguir:

O problema aqui é de ordem prática. Não seria possível deixar para os futuros habitantes do planeta exatamente o mesmo nível ambiental que recebemos pelo simples fato de que o ser humano ao viver sua vida produz continuamente impactos no entorno; não deixar o planeta em pior situação do que a recebida implicaria a paralisação das atividades humanas, o que repercutiria na qualidade de vida dos presentes e mesmo, em alguns casos, na manutenção de sua vida. (SILVA, 2008, p. 50).

Nesse sentido, há até o entendimento de que seria inviável conservar o mesmo nível ambiental que recebemos para titulares que ainda nem existem, devendo ser buscada a tríade do desenvolvimento sustentável, que se traduz na proteção ambiental, desenvolvimento econômico e inclusão social, sendo tais fatores considerados caso a caso, de acordo com as necessidades e características de cada população e "sempre considerando-se um patamar mínimo ambiental sob pena de que todo o ganho econômico e social não possa ser usufruído". (SILVA, 2008, p. 55).

Ainda, tem-se a visão de que a exploração ambiental deve trazer benefícios às minorias e deve ser acompanhada de medidas compensatórias e mitigadoras de impacto:

Na medida do possível, a exploração ambiental deve vir acompanhada de medidas mitigadoras de impacto e mesmo compensatórias. Ao se servir de um determinado ecossistema, o homem deve tentar produzir o menor nível possível de impacto e, não sendo viável, recuperar a área degradada ou mesmo outras áreas próximas, que guardem alguma relação com o local afetado. Assim, deve-

Revista de Direitos Humanos em Perspectiva | e-ISSN: 2526-0197 | Porto Alegre | v. 4 | n. 2 | p. 124 - 145 | Jul/Dez. 2018 
se procurar poupar o bem ambiental, e, sendo impossível, por falta de opção viável, procurar evitar danos de grandes proporções, através de medidas mitigatórias e compensatórias, sendo, que ao final, o produto da manipulação ambiental deve trazer benefícios para a sociedade, notadamente os excluídos. (SILVA, 2008, p. 58).

Na visão crítica de Rawls, "Quando as pessoas são pobres e preservar é difícil, uma taxa menor de preservação deve ser exigida; enquanto que numa sociedade mais rica pode ser razoavelmente esperada uma maior preservação, uma vez que o fardo real de preservar é menor." (RAWLS, 1999, p. 255). No mesmo sentido:

A visão do desenvolvimento sustentável não endossa o sacrifício das legítimas aspirações dos mais pobres em nome das futuras gerações. Ao mesmo tempo, isso de maneira alguma implica que as necessidades das gerações presentes sempre tenham prioridade sobre as das gerações futuras; no mínimo, os mais pobres e mais vulneráveis não deveriam ter que fazer sacrifícios pelo bem da humanidade a longo prazo. (ONU, 2013, p. 5).

Rawls (1999, pp. 251-257) também aborda a questão do quanto as atuais gerações são obrigadas a respeitar as reivindicações de suas sucessoras. Segundo o autor, o embate sobre como especificar o mínimo que deve ser preservado para as gerações futuras traz o problema da justiça entre gerações. Para o autor, para que haja justiça não se pode exigir que as gerações anteriores poupem e preservem simplesmente para que as gerações posteriores sejam mais abastadas, em vez disso, poupar e preservar deve ter o objetivo de concretizar totalmente as instituições e liberdades igualitárias.

Para Rawls (1999, pp. 257-258), os seres humanos de diferentes gerações possuem deveres e obrigações uns em relação aos outros assim como as atuais gerações possuem tais deveres e obrigações entre si. Desta maneira, as presentes gerações não podem simplesmente fazer o que lhes agrada, estando vinculadas aos princípios escolhidos para definir a justiça entre pessoas em diferentes momentos do tempo. Além disso, os seres humanos têm o dever natural de defender e de promover instituições justas e, para isso, é necessária a melhoria da civilização até certo nível. Ainda, nenhuma geração é subordinada a outra e também nenhuma possui reinvindicações mais fortes do que qualquer outra.

O Relatório do Secretário Geral da ONU, da 68ª sessão da Assembleia Geral, nomeado "Intergenerational solidarity and the needs of future generations", traz algumas considerações que clareiam a ideia de solidariedade intergeracional. 
A primeira é que, devido ao fato que não se pode averiguar precisamente as necessidades e preferências das gerações futuras na elaboração de políticas públicas, poder-se-ia levar em conta duas considerações: minimizar os danos e fazer aquilo que beneficia tanto as gerações presentes quanto as futuras. Em vez de procurar identificar e tentar efetivar o que seria uma vida boa para as futuras gerações, o foco político em relação aos direitos de tais gerações deve ser orientado para evitar impactos irreversíveis nos ecossistemas que fornecem a base para a vida humana, tanto agora como no futuro. (ONU, 2013, p. 7).

A segunda, traz a proposição de que, ao levar em conta as necessidades das futuras gerações, seriam favorecidas políticas que funcionem em proveito das presentes e futuras gerações e que, sendo outros fatores mais ou menos iguais, sejam os menos onerosos para a geração atual. (ONU, 2013, pp. 7-8).

A terceira consideração trouxe a proposição de que, quando os riscos para os interesses das futuras gerações sejam razoavelmente claros e consequentes, as presentes gerações devem ser razoáveis e tolerantes, renunciando a alguns benefícios. Isto traduz o princípio da precaução, que, apesar de ser amplamente aceito, ainda não o é universalmente. Nesta categoria entrariam as atividades que causam danos irreversíveis a grandes e importantes ecossistemas ou que causam danos significativos ao capital natural não renovável, não sendo possível sua reparação imediata. Nessa ideia também deve-se escolher as opções com menor risco para atingir um determinado fim. (ONU, 2013, p. 8).

A quarta consideração mostra que a educação tem um papel muito importante na solidariedade intergeracional, no sentido de transmitir o conhecimento acumulado, ou ao menos os mais recentes conhecimentos, científicos ou não, para as futuras gerações. A preocupação com as futuras gerações exige engajamento aberto e crítico em relação às escolhas éticas e morais, sendo tais escolhas conduzidas pelas partes interessadas e informadas em todos os níveis. As possíveis ações seriam o fortalecimento da educação cívica, da educação para o desenvolvimento sustentável e do treinamento de liderança para promover mudanças de atitude que promovam a solidariedade intergeracional e a justiça intergeracional. Então, é importante promover a educação para crianças, jovens e adultos no que diz respeito ao desenvolvimento sustentável e à cidadania global para enfrentar os desafios do século XXI, como maior liberdade e tolerância, bem como a importância de proteger, promover e manter o patrimônio cultural tangível (que 
inclui o patrimônio natural e cultural) e intangível para as gerações atuais e futuras. (ONU, 2013, p. 8).

Por fim, a quinta consideração traz a proposição de que a pesquisa científica e o desenvolvimento científico de longo prazo fazem parte de uma estratégia intergeracional. Isto é necessário para desenvolver substitutos para os recursos esgotados, para extrair e usar os recursos de maneira mais eficiente e para entender e gerenciar as ameaças de longo prazo à qualidade ambiental. Embora grande parte da pesquisa possa ocorrer no setor privado, há uma necessidade de apoio público para estimular mudanças transformadoras em áreas-chave, principalmente onde há falhas de mercado. (ONU, 2013, p. 8).

Portanto, a solidariedade intergeracional é de suma importância para a proteção ambiental das futuras gerações, para que seus direitos humanos, como o direito ao meio ambiente ecologicamente equilibrado, sejam respeitados. Desta maneira, o que se deve buscar é a preservação de um mínimo existencial, colocando em prática os princípios ambientais da prevenção e precaução e utilizando-se a ideia de equidade intergeracional, no sentido de que esse mínimo seria preservar o meio ambiente global o máximo possível para as futuras gerações, mas levando em consideração as questões econômicas e sociais, combatendo a exploração ambiental que ocorre por razões puramente econômicas, mas permitindo-a quando o ganho é social, quando o ganho é para a humanidade e a concretização da dignidade da pessoa humana.

\section{CONCLUSÃO}

De acordo com o presente estudo, ficou evidente que as futuras gerações precisam ter o seu direito ao meio ambiente ecologicamente equilibrado resguardado, e, neste mundo globalizado, a proteção ambiental deve se basear no princípio da solidariedade intergeracional, fundamento dos direitos humanos de terceira dimensão.

Expôs-se que os direitos humanos de terceira dimensão trouxeram o conceito de solidariedade, que é inovador ao estabelecer uma relação de reciprocidade, que se relaciona com os conceitos de equidade e igualdade, formando uma relação horizontalizada, substituindo a relação doador-receptor e dando lugar à relação doador-receptor e receptor-doador, e, que o princípio da solidariedade, após ser reafirmado em diversas normas de soft law, no sentido de 
existir uma imprescindibilidade de solidariedade internacional, está de acordo com a opinio iuris da comunidade internacional, sendo válido e devendo ser efetivado e respeitado em todo o mundo.

Já existindo normas de soft law que trazem o princípio da solidariedade intergeracional, cria-se a expectativa de que essas normas facilitem o convívio das atuais e futuras gerações, para que estas possam desenvolver-se de forma sustentável e de maneira mais humana, com a atuação solidária dos países e transnacionais para que o meio ambiente seja preservado e até mesmo restaurado.

Demonstrou-se que, apesar de existirem efeitos positivos da globalização, como, por exemplo, proporcionar mais qualidade de vida a todos os seres humanos e uma maior prosperidade ao mundo, tais efeitos positivos não vêm se destacando, e o que tem sobressaído são seus efeitos negativos, efeitos globais desordenados aproveitados por transnacionais que buscam o lucro máximo, mesmo que à custa de infrações aos direitos humanos, como a degradação ambiental, colocando o direito ao meio ambiente sadio e equilibrado em risco para as futuras gerações humanas.

Por fim, verificou-se que a solidariedade intergeracional é de suma importância para a proteção ambiental das futuras gerações, para que seus direitos humanos, como o direito ao meio ambiente ecologicamente equilibrado, sejam respeitados. Por isso, deve ser preservado um mínimo existencial, levando em consideração os princípios ambientais da prevenção e precaução, baseando-se na solidariedade intergeracional, no sentido de que esse mínimo seria preservar o meio ambiente global o máximo possível para as futuras gerações, mas levando em consideração as questões econômicas e sociais, combatendo a exploração ambiental que ocorre por razões puramente econômicas, mas permitindo-a quando o ganho é social, quando o ganho é para a humanidade e a concretização da dignidade da pessoa humana.

Mesmo sendo as futuras gerações indeterminadas e indetermináveis, é possível buscar sua proteção através das cinco considerações trazidas no Relatório do Secretário Geral da ONU, da $68^{\mathrm{a}}$ sessão da Assembleia Geral, chamado de "Intergenerational solidarity and the needs of future generations", que podem ser traduzidas nas seguintes recomendações: a) garantir a proteção ao meio ambiente para as futuras gerações, ao buscar evitar e minimizar danos e impactos irreversíveis nos ecossistemas que fornecem a base para a vida humana; b) favorecer 
políticas que beneficiem as presentes e futuras gerações, buscando, quando possível, as ações menos onerosas para as atuais gerações; c) efetivar os princípios ambientais da precaução e da prevenção, escolhendo opções com menor risco ao capital natural e renunciando a certos benefícios quando estes claramente colocarem em riscos direitos das futuras gerações; d) fortalecer a educação, educação para crianças, jovens e adultos, no que diz respeito ao desenvolvimento sustentável e à cidadania global, de maneira a transmitir o conhecimento acumulado através do tempo e promover mudanças de atitude que promovam a solidariedade intergeracional e a justiça intergeracional; e) promover a pesquisa científica e o desenvolvimento científico de longo prazo, com o apoio público e privado, para desenvolver substitutos para os recursos esgotados, extrair e usar os recursos de maneira mais eficiente e entender e gerenciar as ameaças de longo prazo à qualidade ambiental.

Considera-se, portanto, de extrema relevância a exposição realizada acerca dos aspectos principais dos direitos humanos de terceira dimensão, além da sintetização de como se chegou à consagração dos direitos humanos de solidariedade, chegando à solução do problema apresentado neste artigo: o princípio da solidariedade intergeracional pode ser a ferramenta de efetivação da proteção ambiental para as futuras gerações no mundo globalizado atual, pois, com a sua efetivação, é possível a redução da degradação ambiental de maneira a respeitar os Direitos Humanos das presentes e futuras gerações.

\section{REFERÊNCIAS}

AGUILERA URQUIZA, Antonio Hilário; RIBEIRO, Leonardo Cavallini. Paradoxos da globalização, fronteiras culturais e direitos humanos. Revista Direito UFMS: v. 3, n. 2, pp. 241260, 2017. Disponível em: <http://seer.ufms.br/index.php/revdir/article/view/5305>. Acesso em: 13 jun. 2018.

BAUMAN, Zygmunt. A ética é possível num mundo de consumidores? Tradução: Alexandre Werneck, Rio de Janeiro: Jorge Zahar Ed., 2011.

. Globalização: As consequências humanas. Tradução: Marcus Penchel, Rio de Janeiro: Jorge Zahar Ed., 1999.

BONAVIDES, Paulo. Curso de direito constitucional. 15. ed. São Paulo: Malheiros, 2004.

CAMPELLO, Lívia Gaigher Bósio; CALIXTO, Angela Jank. Notas acerca dos direitos humanos de solidariedade. Direito \& Solidariedade. Curitiba: Juruá, 2017. 
CANCIO, Gustavo Santiago Torrecilha; CAMPELLO, Lívia Gaigher Bósio. Divisão Norte-Sul e o Desenvolvimento Sustentável: A Universalidade com Diferenciação Internacional das Responsabilidades Ambientais. CONPEDI Law Review: v. 2, n. 4, pp. 58-74, jul/dez. 2016. Disponível em: <http://www.indexlaw.org/index.php/conpedireview/article/view/3653>. Acesso em: 04 set. 2018.

COMPARATO, Fábio Konder. A afirmação histórica dos direitos humanos. 10. Ed. rev. e atual. São Paulo: Saraiva, 2015.

DECLARAÇÃO DA CONFERÊNCIA DAS NAÇÕES UNIDAS SOBRE MEIO AMBIENTE HUMANO. Declaração de Estocolmo. 1972. Disponível em: <http://www.apambiente.pt/_zdata/Politicas/DesenvolvimentoSustentavel/1972_Declaracao_Esto colmo.pdf>. Acesso em: 02 ago. 2018.

DECLARAÇÃO DO RIO SOBRE MEIO AMBIENTE E DESENVOLVIMENTO. Declaração do Rio de Janeiro sobre Meio Ambiente e Desenvolvimento. 1992. Disponível em: <http://www.scielo.br/pdf/ea/v6n15/v6n15a13.pdf>. Acesso em: 02 ago. 2018.

DUPUY, Pierre-Marie. Soft Law and the International Law of the Enviroment. Michigan Journal of International Law, Vol. 12. 2. ed. Michigan - Estados Unidos da América. 1991. Disponível em: <http://repository.law.umich.edu/mjil/vol12/iss2/4>. Acesso em: 08 mai. 2018.

MARQUES, Clarissa. Meio ambiente, solidariedade e futuras gerações. Revista do Programa de Pós-Graduação em Direito da UFC. v. 32, n. 2, pp. 37-56, 2012. Disponível em: <http://periodicos.ufc.br/nomos/article/view/350>. Acesso em: 04 jun. 2018.

MELEU, Marcelino da Silva; BANDEIRA, Laís Cristina. A solidariedade como base para efetivação dos direitos humanos no âmbito internacional. Revista Direito UFMS. v. 3, n. 1, pp. 259-274, 2017. Disponível em: <http://seer.ufms.br/index.php/revdir/article/view/4074/3303>. Acesso em: 14 jun. 2018.

MONTESQUIEU, Charles-Louis de Secondat de. Euvres completes de Montesquieu. Tome Second (Vol. II). Ire Partie ( ${ }^{\mathrm{a}}$ parte). Paris: A. Belin, 1817. Disponível em: <https://books.google.com.br/books?id=OBUTAAAAQAAJ>. Acesso em: 18 jun. 2018

MORAES, K. G. Obsolescência Planejada de Qualidade: Fundamentos e Perspectivas Jurídicoambientais de Enfrentamento. 2013. Dissertação (Mestrado em Direito) - Universidade Federal de Santa Catarina, Florianópolis, 2013. Disponível em: <https://repositorio.ufsc.br/handle/123456789/107281>. Acesso em: 04 set. 2018.

PISSALDO, Ana Paula de Moraes. Efetivação da terceira dimensão dos direitos humanos pelas empresas transnacionais no contexto do capitalismo neoliberal. 105 f. Dissertação (mestrado) Universidade Nove de Julho - UNINOVE, São Paulo, 2015. Disponível em: <http://bibliotecatede.uninove.br/handle/tede/1219>. Acesso em 26 jun. 2018. 
RAWLS, John. A Theory of Justice. ed. rev. Cambridge: Harvard University Press, 1999.

RELATÓRIO DA COMISSÃO MUNDIAL SOBRE MEIO AMBIENTE E DESENVOLVIMENTO: Nosso Futuro Comum. 1987. Disponível em: <www.undocuments.net/our-common-future.pdf>. Acesso em: 28 jun. 2018.

SANCHES, Samyra Haydêe Dal Farra Naspolini. Direitos Humanos e a empresa privada no Brasil. In: SILVEIRA, Vladmir Oliveira da; MEZZAROBA, Orides (Coord.); MAILLART, Adriana S.; COUTO, Monica Bonetti ET AL (org.). Empresa, Sustentabilidade $e$ Funcionalização do Direito. Coleção: Justiça, Empresa e Sustentabilidade. Vol. 2. pp. 294-307. São Paulo: Revista dos Tribunais, 2011.

SILVA, Betina Günter. Justiça ambiental intergeracional. 2008. Dissertação (Mestrado em Direito Público), Faculdade Mineira de Direito. Pontifícia Universidade Católica de Minas Gerais, Belo Horizonte. 〈www.biblioteca.pucminas.br/teses/Direito_SilvaBG_1.pdf>. Acesso em: 27 jul. 2018.

SILVEIRA, Vladmir Oliveira da. Direitos Humanos Fundamentais das Pessoas com Deficiência. Revista Direito UFMS. Edição Especial, pp. 103-130, jan./jun. 2015. Disponível em: <http://seer.ufms.br/index.php/revdir/article/view/1235>. Acesso em: 16 jun. 2018.

SILVEIRA, Vladmir Oliveira da. ROCASOLANO, Maria Mendez. Direitos Humanos: Concepções, Significados e Funções. São Paulo: Saraiva, 2010.

TORRADO, Jesus Lima. Problemas Conciernentes a la ambigüedad conceptual y terminológica de la globalización y su incidencia ideológica sobre el sistema de derechos humanos. Revista de Administración Pública, n. 105, Madrid, UNAM, 2012. Disponível em: $<$ http://historico.juridicas.unam.mx/publica/rev/indice.htm?r=rap\&n=105>. Acesso em: 16 jun. 2018.

WEISS, Edith Brown. Intergenerational equity: a legal framework for global environmental change. Environmental change and international law: New challenges and dimensions. Tokyo: United Nations University Press, 1992. Disponível em: <http://www.unu.edu/unupress/unupbooks/uu25ee/uu25ee0y.htm\#12.\%20intergenerational\%20e quity:\%20a\%20legal\%20framework\%20for\%20global\%20environmental\%20change>. Acesso em: 02 ago. 2018.

WEISS, Edith Brown; D'AMATO, Anthony; GÜNDLING, Lothar. Agora: what obligation does our generation owe to the next? An approach to global environmental responsibility. Cambridge University Press: American Journal of International Law. v. 84, n. 1, pp. 190-198, 1990. Disponível em: <https://www.jstor.org/stable/2203019>. Acesso em: 03 ago. 2018. 